\title{
Penentuan Harga Tandan Buah Segar (TBS) Kelapa Sawit Menggunakan Metode Fuzzy Logic
}

\author{
Amriana $^{\mathrm{a}, 1}$, Anita Ahmad Kasim ${ }^{\mathrm{a}, 2}$ dan Maghfirat a,3,* \\ ${ }^{a}$ Universitas Tadulako, Jl. Soekarno Hatta No.KM. 9, Tondo, Palu, 94148, Indonesia \\ Iamrianaa23@gmail.com; ${ }^{2}$ nita.kasim@gmail.com; ${ }^{3}$ dedeaat@yahoo.com; \\ *corresponding author
}

\begin{tabular}{|c|c|}
\hline INFORMASI ARTIKEL & ABSTRAK \\
\hline $\begin{array}{l}\text { Dikirim : 12 Agustus 2020 } \\
\text { Diulas } \quad: 05 \text { Desember } 2020 \\
\text { Direvisi : 13 Desember } 2020 \\
\text { Diterbitkan }: 28 \text { Desember } 2020 \\
\\
\text { Kata Kunci: } \\
\text { Penentuan } \\
\text { Harga } \\
\text { Tandan Buah Segar } \\
\text { Kelapa Sawit } \\
\text { Fuzzy Logic }\end{array}$ & $\begin{array}{l}\text { Tujuan penelitian ini adalah membuat sistem penentuan harga Tandan Buah Segar } \\
\text { kelapa sawit menggunakan metode Fuzzy Logic. Perkebunan kelapa sawit adalah } \\
\text { perkebunan yang memiliki sumber daya alam yang dapat menghasilkan } \\
\text { keuntungan besar, karena digunakan sebagai minyak goreng dan masih banyak } \\
\text { lagi. TBS kelapa sawit terdiri dari Crude Palm Oil (CPO) yaitu minyak daging } \\
\text { buah dan Palm Kernel (PK) yaitu inti biji sawit. Penelitian ini membuat sistem } \\
\text { menggunakan } 5 \text { variabel input yaitu harga CPO, harga IKS, Indeks K, Rendemen } \\
\text { CPO dan Rendemen IKS, serta satu variabel output yaitu harga TBS kelapa sawit. } \\
\text { Sistem ini menggunakan metode Fuzzy Logic karena dalam penelitian ini terdapat } \\
\text { suatu fuzzy yang dapat ditentukan, yaitu harga TBS kelapas sawit. Sistem ini } \\
\text { menggunakan } 100 \text { data untuk diuji menggunakan MAPE sehingga didapatkan } \\
\text { nilai persentase sebesar } 85.75 \% \text {. Sedangkan nilai rata-rata dari selisih antara data } \\
\text { aktual dengan data hasil fuzzy mamdani adalah sebesar } 17852 \text { dengan rata-rata } \\
\text { persentase kesalahan dari fuzzy mamdani adalah sebesar } 14.25 \% \text {. Hasil dari } \\
\text { sistem ini adalah variabel output harga TBS kelapa sawit berdasarkan } 5 \text { variabel } \\
\text { input. Metode Fuzzy Logic Mamdani menentukan hasil dari nilai yang tidak pasti. } \\
\text { Proses fuzzy logic dimulai dari pembentukan himpunan fuzzy, kemudian aplikasi } \\
\text { fungsi implikasi, lalu tahap komposisi aturan, setelah itu tahap deffuzifikasi. }\end{array}$ \\
\hline
\end{tabular}

Keywords:

Determination

Price

Fresh Fruit Bunches

Palm Oil

Fuzzy Logic

\begin{abstract}
The purpose of this study is to create a system for determining the price of oil palm fresh fruit bunches using the Fuzzy Logic method. Oil palm plantations are plantations that have natural resources that can generate large profits, which are used as cooking oil and much more. Palm oil FFB consists of Crude Palm Oil (CPO), which is fruit flesh oil and Palm Kernel (PK), which is the kernel of palm oil. This research makes the system use 5 input variables that is CPO price, IKS price, K Index, CPO Rendemen and IKS Rendemen, and one output variable which is the price of oil palm FFB. This system uses the Fuzzy Logic method because in this study there is fuzzy that can be determined, namely the price of oil palm-based TBS. This system uses 100 data to request using MAPE so that a percentage value is $85.75 \%$. While the average value of the difference between the actual data and the results of the fuzzy Mamdani data is 17852 with an average percentage of errors of the fuzzy Mamdani data is $14.25 \%$. The result of this system is the variable price of oil palm FFB output based on 5 variable inputs. The Mamdani Fuzzy Logic method determines the outcome of an uncertain value. Fuzzy logic starts from the formation of fuzzy sets, then implications, then rules, and then defuzzification.
\end{abstract}

This is an open access article under the CC-BY-SA license.

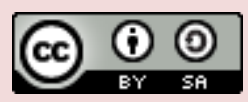

\section{Pendahuluan}

Indonesia adalah negara yang memiliki banyak sumber daya alam dibidang perkebunan. Perkembangan dunia teknologi informasi yang luar biasa bagi kemajuan peradaban umat manusia bisa membantu pekerjaan khususnya dalam bidang perkebunan. Salah satu perkebunan yang kaya akan sumber daya alam di Indonesia yaitu perkebunan kelapa sawit karena kondisi geografisnya sangat cocok untuk pengembangan perkebunan kelapa sawit. Kelapa sawit dapat digunakan sebagai minyak goreng, bahan bakar untuk kendaraan, bahan didapur, kosmetik dan masih banyak lagi. Kelapa sawit (Elaeis guineensis Jacq.) adalah jenis tanaman yang 
penting bagi bidang perkebunan dimana dapat memberikan pendapat bagi petani dan masyarakat [1]. Hasil dari tanaman kelapa sawit adalah buah kelapa sawit atau Tandan Buah Segar (TBS) yang membentuk buah pada umur 2-3 tahun [2].

Di Sulawesi Tengah terdapat banyak kebun kelapa sawit yang diolah oleh perusahaan dan pekebun, seperti Morowali, Morowali Utara, Luwuk dan Buol. Pekebun memanen Tandan Buah Segar (TBS) kelapa sawit dan dibawa ke perusahaan untuk diolah sehingga digunakan untuk kebutuhan manusia. Setiap perusahaan menyampaikan dokumen harga dan jumlah penjualan Crude Palm Oil (CPO) dan Palm Kernel (PK) paling kurang 1 kali setiap bulan kepada Dinas Perkebunan dan Peternakan Provinsi Sulawesi Tengah untuk diklarifikasi oleh tim penetapan harga pembelian TBS. CPO adalah minyak daging buah dan PK adalah inti biji sawit. Setiap perusahaan melaporkan usulan harga TBS kelapa sawit ke Dinas Perkebunan dan Peternakan untuk ditetapkan harga TBS kelapa sawit. Menurut Republik Indonesia (2018), tujuan dari penetapan harga TBS Kelapa Sawit adalah baik pekebun dan perusahaan mendapatkan harga yang wajar dan tidak ada yang dirugikan. [3].

Penelitian "Peramalan CPO menggunakan Support Vector Regression (SVR)" bertujuan untuk memprediksi harga CPO menggunakan SVR. Persamaan dari penelitian ini dengan penelitian yang dilakukan oleh penulis adalah membahas tentang kelapa sawit. Perbedaannya adalah penulis mengolah data TBS Kelapa Sawit yang terdiri dari minyak sawit kasar (CPO) dan inti sawit (IKS) dan menentukannya dengan menggunakan metode fuzzy logic, sedangkan penelitian ini mengolah data CPO dan melakukan peramalan harga CPO menggunakan metode SVR [4].

Penelitian "Implementasi Metode Backpropagation untuk Prediksi Harga Jual Kelapa Sawit Berdasarkan Kualitas Buah", bertujuan untuk memprediksi harga jual kelapa sawit menggunakan metode Jaringan Syaraf Tiruan Backpropagation. Persamaan penelitian di atas dengan penelitian yang dilakukan oleh penulis yaitu kedua-duanya meneliti tentang kelapa sawit, sedangkan perbedaannya adalah penelitian ini menggunakan metode Jaringan Syaraf Tiruan Backpropagation, sedangkan penelitian yang dilakukan oleh penulis menggunakan metode fuzzy logic Mamdani [5].

Penelitian "Implementasi Metode Backpropagation untuk Klasifikasi Kenaikan Harga Minyak Kelapa Sawit". Harga sangat penting dalam penentuan nilai jual produk dan keuntungan produsen berpengaruh juga, sehingga naik atau turunnya harga minyak kelapa sawit membuat konsumen mempertimbangkan kembali untuk membelinya. Tujuan dari penelitian ini adalah mengklasifikasi harga minyak kelapa sawit dengan menggunakan metode Backprogation. Persamaan dari penelitian ini dengan penelitian yang dilakukan oleh penulis adalah membahas tentang kelapa sawit. Perbedaannya adalah penelitian diatas mengklasifikasi kenaikan harga minyak kelapa sawit yang akan datang, sedangkan penelitian yang dilakukan penulis menentukan harga TBS kelapa sawit menggunakan metode fuzzy logic [6].

Prediksi “Produksi Minyak Kelapa Sawit Menggunakan Metode Backpropagation Neural Network”. Tujuan penelitian ini untuk memprediksi produksi minyak kelapa sawit mentah menggunakan Backpropagation Neural Network. Persamaan penelitian ini dengan penelitian yang dilakukan oleh penulis adalah membahas tentang kelapa sawit. Perbedaannya adalah penelitian diatas memprediksi jumlah produksi dari minyak kelapa sawit menggunakan metode Backpropagation Neural Network, sedangkan penelitian penulis menentukan harga TBS Kelapa Sawit menggunakan metode Fuzzy Logic [7].

“Penerapan Metode Fuzzy Mamdani Untuk Memprediksi Jumlah Produksi Karet”. Tujuan penelitian ini adalah memprediksi jumlah produksi karet menggunakan metode fuzzy mamdani. Persamaan penelitian diatas dengan penelitian yang dilakukan oleh penulis adalah menggunakan metode fuzzy mamdani. Perbedaannya adalah penelitian diatas memprediksi jumlah produksi karet, sedangkan penelitian yang dilakukan oleh penulis menentukan harga TBS kelapa sawit [8].

Penelitian "Implementasi Metode Tsukamoto Pada Analisis Prediksi Hasil Kelapa Sawit” bertujuan untuk menghasilkan prediksi hasil kelapa sawit menggunakan metode Fuzzy Inference System Tsukamoto. Variabel fuzzy yang digunakan pada penelitian ini adalah wilayah, luas tanah (ha), dan jumlah pokok. Persamaan penelitian diatas dengan penelitian yang dilakukan oleh penulis adalah menggunakan metode fuzzy logic. Perbedaannya adalah penelitian diatas menggunakan fuzzy inference system Tsukamoto berupa 3 variabel fuzzy dengan menggunakan Matlab, sedangkan penelitian yang dilakukan oleh penulis menggunakan fuzzy inference system Mamdani berupa 6 variabel fuzzy dengan menggunakan Web [9].

Dalam bidang teknologi informasi, banyak informasi kelapa sawit yang dapat diolah dengan menggunakan berbagai teknologi yang ada. Salah satunya adalah metode fuzzy logic. Dalam menentukan harga TBS kelapa sawit menggunakan fuzzy logic, variabel dibagi atas variabel input yaitu harga CPO lokal, harga Inti Kelapa Sawit (IKS), Indeks K, Rendemen CPO dan Rendemen IKS serta variabel output yaitu harga TBS kelapa sawit. Variabel harga CPO, harga IKS, indeks K, dan harga TBS kelapa sawit dibagi menjadi 3 kategori, yaitu rendah, sedang dan tinggi, sedangkan variabel rendemen CPO dan rendemen IKS dibagi menjadi 2 kategori, yaitu turun dan naik. Fuzzy logic dapat memasukkan nilai pada rentang 0 sampai 1, sehingga nilai yang nanti akan 
dimasukkan dapat berpengaruh saat pemilihan kategori dalam variabel, sehingga fuzzy logic dapat membantu menghasilkan keluaran dari nilai yang tidak tetap.

Dalam TBS kelapa sawit, fuzzy yang ada dalam TBS kelapa sawit adalah harganya. Setiap orang mempunyai pendapat masing-masing terhadap harga, apakah harganya rendah, sedang, tinggi, dan lain-lain. Dalam fuzzy logic, terdapat nilai/persentase dari setiap parameter yang ada, baik harga rendah, sedang dan tinggi sehingga setiap parameter mempunyai nilai masing-masing. Harga TBS kelapa sawit dapat ditentukan untuk bulan yang diusulkan oleh perusahaan. Penelitian ini bertujuan untuk menghasilkan sistem untuk mendata harga Tandan Buah Segar (TBS) Kelapa Sawit dan meneliti dalam penentuan harga TBS Kelapa Sawit menggunakan metode Fuzzy Logic.

\section{Metode}

\section{A. Tahapan dan Diagram Alir Penelitian}

Adapun tahapan dalam penelitian ini dapat dilihat pada flowchart Gambar 1:

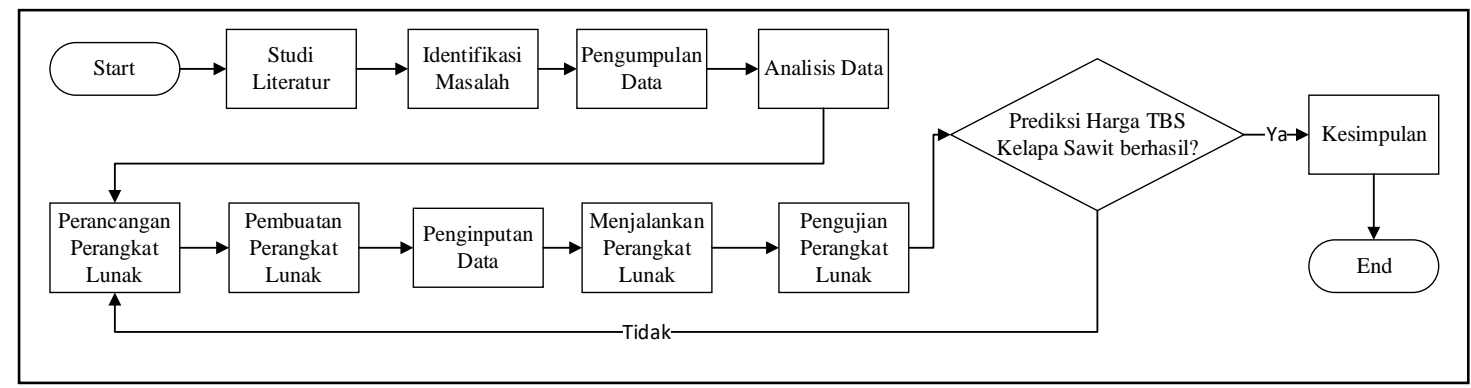

Gambar 1. Flowchart Tahapan Penelitian

\section{B. Logika Fuzzy}

Logika fuzzy mengatasi suatu hal yang tidak pasti di segala bidang. Logika fuzzy dapat digunakan pada kasus yang susah dijelaskan dengan model matematika. Fuzzy set terdiri dari informasi yang jelas untuk memecahkan suatu masalah [10].

\section{Himpunan Fuzzy}

Perbedaan himpunan fuzzy dengan himpunan crisp (tegas) yaitu nilai keanggotaan pada himpunan crisp yaitu 0 dan 1, sedangkan himpunan fuzzy yaitu antara 0 sampai 1 [11].

\section{Atribut Himpunan Fuzzy}

Atribut himpunan fuzzy terdiri dari linguistik dan numeris. Linguistik berupa nama yang mewakili suatu keadaan tertentu, seperti muda, parobaya, tua. dan numeris berupa ukuran dari variabel yang digunakan yang berupa angka, seperti 40, 25, 50. [11].

\section{E. Semesta Pembicaraan}

Semesta pembicaraan adalah batasan nilai yang bisa diproses dalam suatu variabel fuzzy [12].

\section{F. Fungsi Keanggotaan}

Fungsi keanggotaan (membership function) adalah kurva/grafik yang terdiri atas titik-titik domain himpunan fuzzy untuk menghasilkan nilai keanggotaan [11]. Ada beberapa bentuk representasi dalam fungsi keanggotaan, diantaranya:

1) Representasi Linier. Fungsi ini terdiri dari 2 parameter yang terdiri dari a dan b. Dalam representasi linier ada dua keadaan, yaitu linier naik dan linier turun [13]. Fungsi keanggotaan linear naik dapat dilihat pada Gambar 2 dan fungsinya pada persamaan (1) [14]:

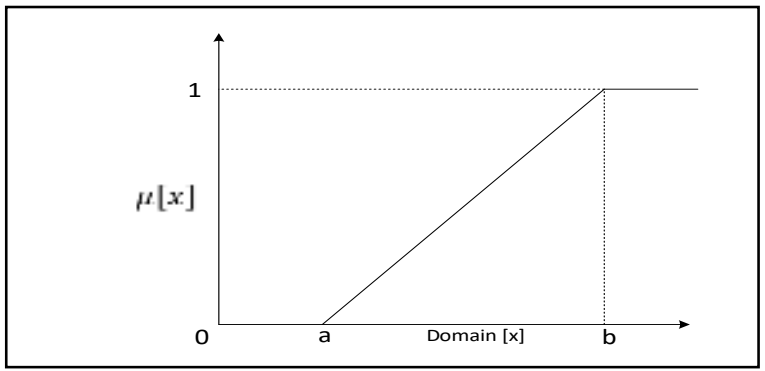

Gambar 2. Fungsi Linear Naik [14] 


$$
\mu[x]=\left\{\begin{array}{cc}
0 ; & x \leq a \\
(x-a) /(b-a) ; & a \leq x \leq b \\
1 ; & x \geq b
\end{array}\right.
$$

Fungsi keanggotaan linear turun dapat dilihat pada Gambar 3 dan fungsinya pada persamaan (2) [14]:

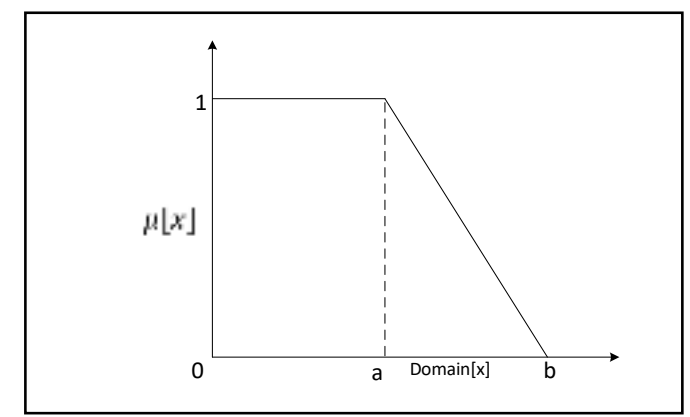

Gambar 3. Fungsi Linear Turun [14]

$$
\mu[x]=\left\{\begin{array}{cc}
1 ; & x \leq a \\
(b-x) /(b-a) ; & a \leq x \leq b \\
0 ; & x \geq b
\end{array}\right.
$$

2) Representasi Kurva Segitiga, fungsi ini terdiri dari 3 parameter yang terdiri dari a,b dan c. [13]. Fungsi keanggotaan segitiga dapat dilihat pada Gambar 4 dan fungsinya pada persamaan (3) [14]:

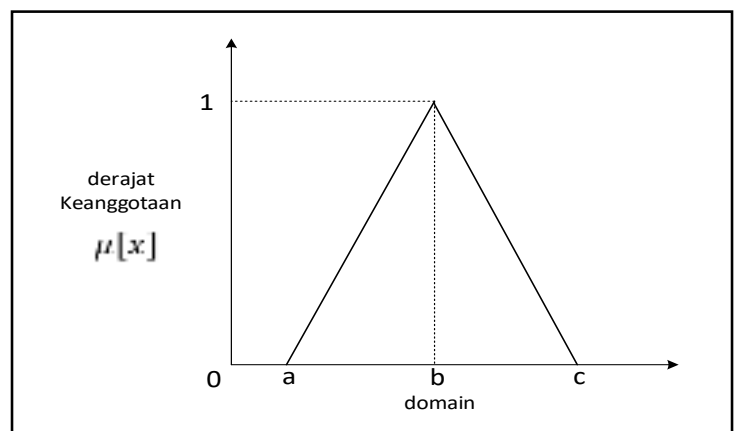

Gambar 4. Fungsi Kurva Segitiga [14]

$$
\mu[x]=\left\{\begin{array}{cc}
0 ; & x \leq \text { a atau } x \geq c \\
(x-a) /(b-a) ; & a \leq x \leq b \\
(b-x) /(c-b) ; & b \leq x \leq c
\end{array}\right.
$$

\section{G. Model Mamdani}

Ada 4 tahapan pada logika fuzzy metode mamdani, yaitu: [11]:

1) Menentukan himpunan fuzzy yang digunakan dalam setiap variabel fuzzy..

2) Fungsi Implikasi (Aturan), dalam tahap ini, metode Min digunakan dalam fungsi implikasi.

3) Komposisi Aturan, dalam tahap ini, metode Max digunakan dalam komposisi aturan.

4) Defuzzifikasi. Mengembalikan nilai himpunan fuzzy menjadi himpunan crisp.

\section{Hasil dan Pembahasan}

Sistem yang dibuat oleh penulis berbasis Web untuk menampilkan informasi data teks dan data gambar [15]. Sistem ini menggunakan framework codeigniter yang terdiri dari function-function dengan fungsi masingmasing dan menggunakan metode Model, View, Controller (MVC) [15]. Data TBS disimpan dalam basis data MySQL sebagai bahan dasar untuk mengakses databasenya dan termasuk jenis RDBMS [16]. Untuk menentukan harga TBS kelapa sawit, dimulai dari penginputan data TBS yang diperoleh langsung dari objek penelitian, untuk digunakan sebagai acuan untuk variabel input di fuzzy logic. Representasi Pengetahuan yang digunakan terdiri dari fungsi keanggotaan variabel dan fungsi implikasi yang digunakan. Fungsi keanggotaan variabel yang digunakan terdiri dari 5 variabel input yaitu Harga CPO, Harga IKS, Indeks K, Rendemen CPO, Rendemen IKS, dan 1 variabel output yaitu Harga TBS Kelapa Sawit:

1) Harga CPO (Crude Palm Oil) adalah harga atau nilai realisasi rata-rata tertimbang penjualan ekspor dan lokal minyak sawit kasar (Harga FOB Bersih). Variabel ini memiliki 3 himpunan fuzzy, yaitu rendah, 
sedang, dan tinggi. Nilai inputan variabel harga CPO dimisalkan sebagai x untuk mendapatkan nilai himpunan fuzzy berdasarkan fungsi keanggotaan variabel harga CPO yang dapat dilihat pada Gambar 5 dan fungsinya pada persamaan (4),(5) dan (6):

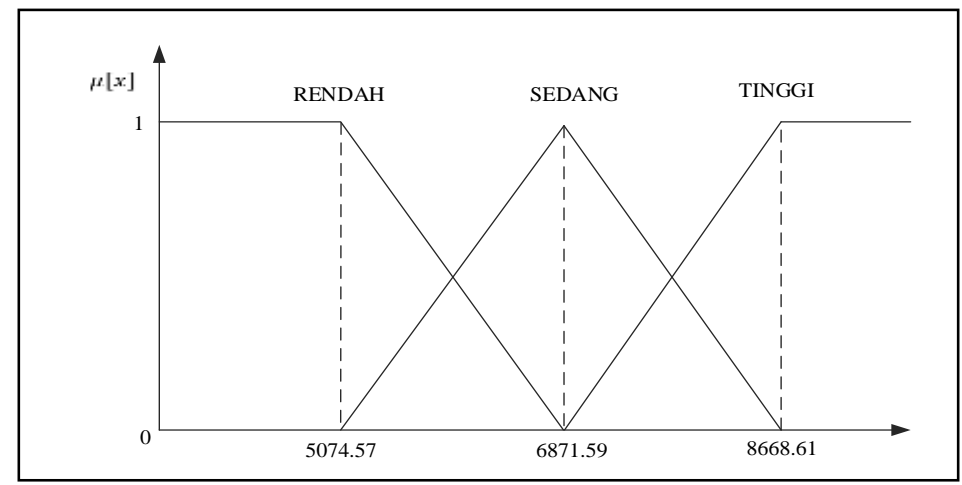

Gambar 5. Fungsi Keanggotaan Variabel Harga CPO

$$
\begin{aligned}
& \mu \text { CpoRENDAH[x] }=\left\{\begin{array}{cc}
1 ; & x \leq 5074.57 \\
\frac{6871.59-x}{6871.59-5074.57} ; & 5074.57 \leq x \leq 6871.59 \\
0 ; & x \geq 6871.59
\end{array}\right. \\
& \mu \text { CpoSEDANG }[x]=\left\{\begin{array}{cc}
0 ; & x \leq 5074.57 \text { atau } x \geq 8668.61 \\
\frac{x-5074.57}{6871.59-5074.57} ; & 5074.57 \leq x \leq 6871.59 \\
\frac{8668.61-x}{8668.61-6871.59} ; & 6871.59 \leq x \leq 8668.61
\end{array}\right. \\
& \mu \text { CpoTINGGI }[x]=\left\{\begin{array}{cc}
0 ; & x \leq 6871.59 \\
\frac{x-6871.59}{8668.61-6871.59} ; & 6871.59 \leq x \leq 8668.61 \\
1 ; & x \geq 8668.61
\end{array}\right.
\end{aligned}
$$

2) Harga IKS (Inti Kelapa Sawit) adalah harga atau nilai realisasi rata-rata tertimbang penjualan lokal inti kelapa sawit (Harga FOB Bersih). Variabel ini memiliki 3 himpunan fuzzy, yaitu rendah, sedang dan tinggi. Nilai inputan variabel harga IKS dimisalkan sebagai $x$ untuk mendapatkan nilai himpunan fuzzy berdasarkan fungsi keanggotaan variabel harga IKS yang dapat dilihat pada Gambar 6 dan fungsinya pada persamaan (7),(8) dan (9):

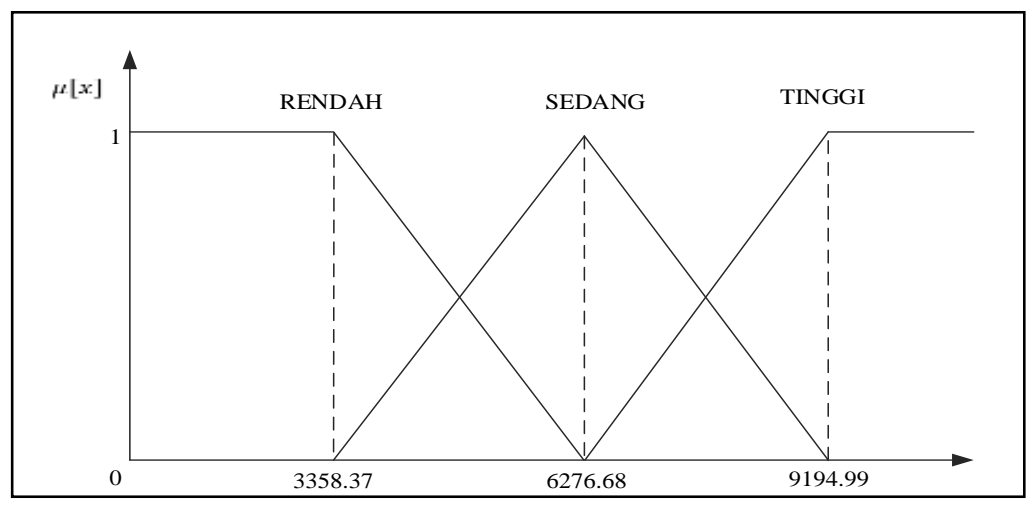

Gambar 6. Fungsi Keanggotaan Variabel Harga IKS

$$
\begin{aligned}
& \mu I k s R E N D A H[x]=\left\{\begin{array}{cc}
1 ; & x \leq 3358.37 \\
\frac{6276.68-x}{6276.68-3358.37} ; & 3358.37 \leq x \leq 6276.68 \\
0 ; & x \geq 6276.68
\end{array}\right. \\
& \mu \operatorname{IkSSEDANG}[x]=\left\{\begin{array}{cc}
0 ; & x \leq 3358.37 \text { atau } x \geq 9194.99 \\
\frac{x-3358.37}{6276.68-3358.37} ; & 3358.37 \leq x \leq 6276.68 \\
\frac{9194.99-x}{9194.99-6276.68} ; & 6276.68 \leq x \leq 9194.99
\end{array}\right.
\end{aligned}
$$




$$
\mu I k s T I N G G I[x]=\left\{\begin{array}{cc}
0 ; & x \leq 6276.68 \\
\frac{x-6276.68}{9194.99-6276.68} ; & 6276.68 \leq x \leq 9194.99 \\
1 ; & x \geq 9194.99
\end{array}\right.
$$

3) Indeks $\mathrm{K}$ adalah nilai yang didapatkan oleh pekebun dalam bentuk persentase setelah proses pengolahan TBS di pabrik perusahaan. Variabel ini memiliki 3 himpunan fuzzy, yaitu rendah, sedang dan tinggi. Nilai inputan variabel indeks $\mathrm{K}$ dimisalkan sebagai $\mathrm{x}$ untuk mendapatkan nilai himpunan fuzzy berdasarkan fungsi keanggotaan variabel Indeks K yang dapat dilihat pada Gambar 7 dan fungsinya pada persamaan (10),(11) dan (12):

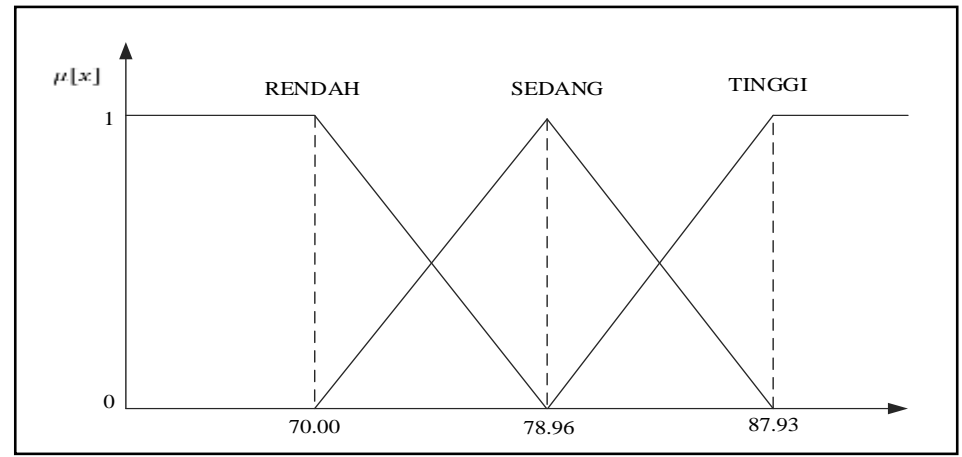

Gambar 7. Fungsi Keanggotaan Variabel Indeks K

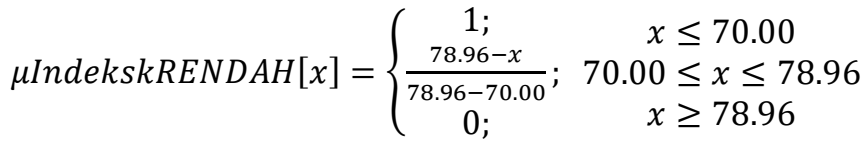

$$
\begin{aligned}
& \mu \text { IndekskSEDANG }[x]=\left\{\begin{array}{cc}
0 ; & x \leq 70.00 \text { atau } x \geq 87.93 \\
\frac{x-70.00}{78.96-70.00} ; & 70.00 \leq x \leq 78.96 \\
\frac{87.93-x}{87.93-78.96} ; & 78.96 \leq x \leq 87.93
\end{array}\right.
\end{aligned}
$$

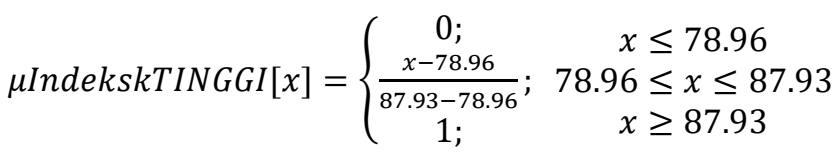

4) Rendemen CPO adalah perbandingan jumlah antara minyak kelapa sawit kasar yang diproduksi dalam setiap kilokgram TBS. Variabel ini memiliki 2 himpunan fuzzy, yaitu turun dan naik. Nilai inputan variabel rendemen CPO dimisalkan sebagai x untuk mendapatkan nilai himpunan fuzzy berdasarkan fungsi keanggotaan variabel Rendemen CPO yang dapat dilihat pada Gambar 8 dan fungsinya pada persamaan (13) dan (14):

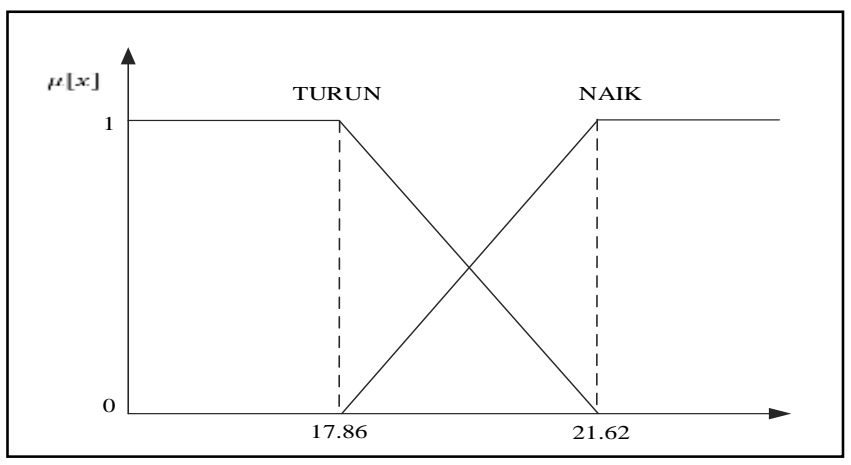

Gambar 8. Fungsi Keanggotaan Variabel Rendemen CPO

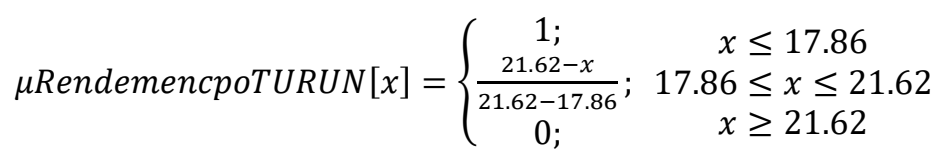




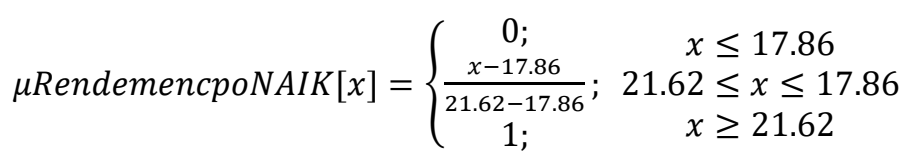

5) Rendemen IKS adalah perbandingan jumlah antara inti kelapa sawit yang diproduksi dalam setiap kilogram TBS. Variabel ini memiliki 2 himpunan fuzzy, yaitu turun dan naik. Nilai inputan variabel rendemen IKS dimisalkan sebagai x untuk mendapatkan nilai himpunan fuzzy berdasarkan fungsi keanggotaan variabel Rendemen IKS yang dapat dilihat pada Gambar 9 dan fungsinya pada persamaan (15) dan (16):

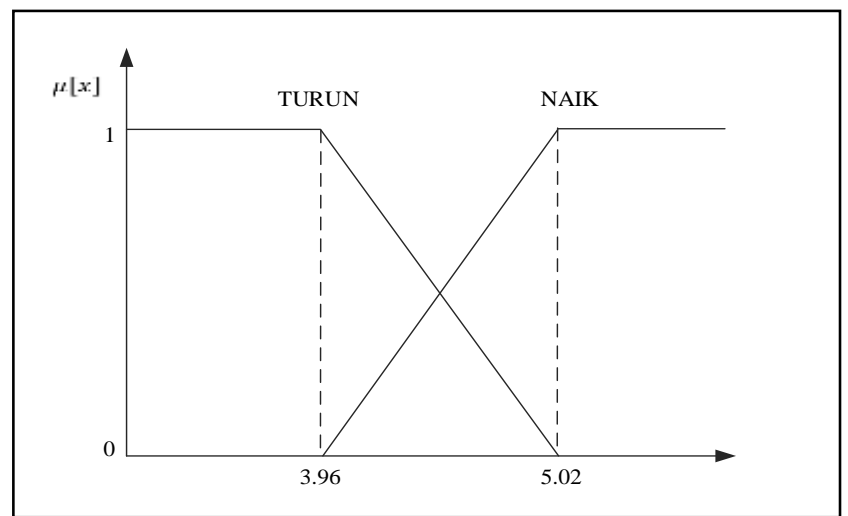

Gambar 9. Fungsi Keanggotaan Variabel Rendemen IKS

$$
\begin{aligned}
& \mu \text { RendemeniksRENDAH }[x]=\left\{\begin{array}{cc}
1 ; & x \leq 3.96 \\
\frac{5,02-x}{5,02-3.96} ; & 3.96 \leq x \leq 5,02 \\
0 ; & x \geq 5,02
\end{array}\right. \\
& \mu \text { RendemeniksTINGGI }[x]=\left\{\begin{array}{cc}
0 ; & x \leq 3.96 \\
\frac{x-3.96}{5.02-3.96} ; & 5,02 \leq x \leq 3.96 \\
1 ; & x \geq 5,02
\end{array}\right.
\end{aligned}
$$

6) Harga TBS Kelapa Sawit adalah produk awal kelapa sawit yang akan diolah sehingga menghasilkan minyak kelapa sawit kasar dan inti kernel. Variabel ini memiliki 3 himpunan fuzzy, yaitu rendah, sedang dan tinggi. Nilai inputan variabel harga CPO dimisalkan sebagai x untuk mendapatkan nilai himpunan fuzzy berdasarkan fungsi keanggotaan variabel harga TBS Kelapa Sawit yang dapat dilihat pada Gambar 10 dan fungsinya pada persamaan (17),(18) dan (19):

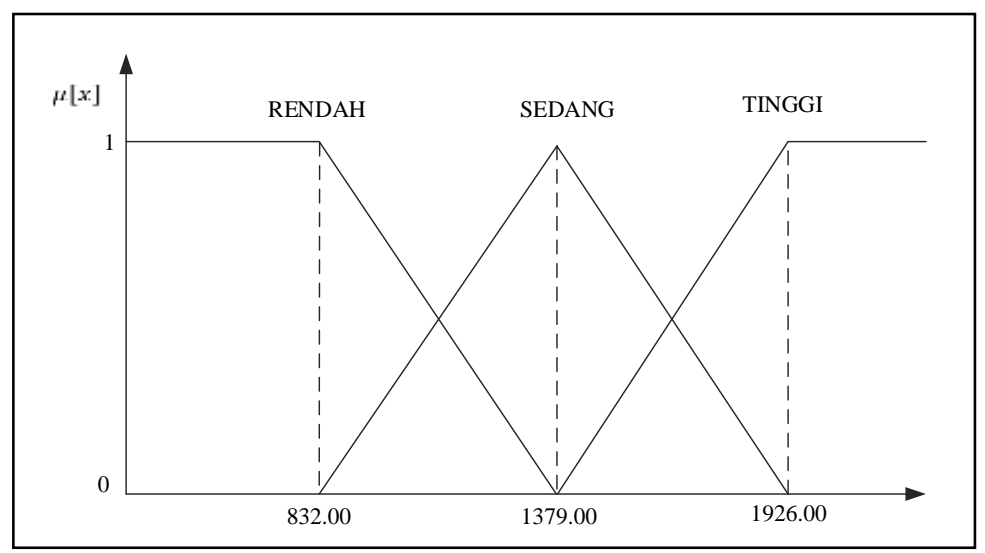

Gambar 10. Fungsi Keanggotaan Variabel Harga TBS Kelapa Sawit

$$
\mu T b s R E N D A H[x]=\left\{\begin{array}{cc}
1 ; & x \leq 832.00 \\
\frac{1379.00-x}{1379.00-832.00} ; & 832.00 \leq x \leq 1379.00 \\
0 ; & x \geq 1379.00
\end{array}\right.
$$




$$
\begin{aligned}
& \mu \text { TbsSEDANG }[x]=\left\{\begin{array}{cc}
0 ; & x \leq 832.00 \text { atau } x \geq 1926.00 \\
\frac{x-832.00}{1379.00-832.00} ; & 832.00 \leq x \leq 1379.00 \\
\frac{1926.00-x}{1926.00-1379.00} ; & 1379.00 \leq x \leq 1926.00
\end{array}\right. \\
& \mu \text { TbsTINGGI }[x]=\left\{\begin{array}{cc}
0 ; & x \leq 1379.00 \\
\frac{x-1379.00}{1926.00-1379.00} ; & 1379.00 \leq x \leq 1926.00 \\
1 ; & x \geq 1926.00
\end{array}\right.
\end{aligned}
$$

Berdasarkan fungsi keanggotaan dari variabel-variabel diatas, fungsi keanggotaan variabel input berfungsi untuk menghasilkan nilai setiap himpunan fuzzy dari 0 sampai 1 dari inputan nilai setiap variabel input. Setelah semua nilai himpunan fuzzy pada setiap variabel input diperoleh, kemudian diproses fungsi implikasi yaitu menerapkan ke 108 rule yang ada dan diambil nilai min dari setiap aturan. Lalu menggunakan komposisi aturan yaitu mengambil nilai max dari hasil variabel output dari aturan yang ada pada tahap sebelumnya. Kemudian tahap deffuzifikasi agar nilai fuzzy diproses menjadi himpunan crisp sehingga hasilnya mudah dipahami.

\section{IV.Kesimpulan}

Sistem penentuan dibangun berdasarkan fungsi keanggotaan dari 5 variabel input yang terdiri dari harga $\mathrm{CPO}$, harga IKS, indeks K, rendemen CPO, rendemen IKS dan 1 variabel output yaitu harga TBS kelapa sawit, serta rules yang dibuat berdasarkan fungsi keanggotaan, dan menggunakan metode Mamdani. Metode pengujian akurasi yang digunakan adalah Mean Absolute Percent Error (MAPE) yaitu metode peramalan dalam bentuk persentase yang didapat dari rata-rata diferensiasi absolut antara nilai peramalan dan nilai yang sebenarnya [17]. Berdasarkan hasil pengujian akurasi, dapat diketahui dari 100 data yang diuji, diperoleh tingkat akurasi $85.75 \%$. Nilai rata-rata dari selisih antara hasil studi kasus dengan hasil fuzzy mamdani adalah sebesar 17852 dengan ratarata persentase kesalahan dari metode mamdani adalah sebesar $14.25 \%$.

\section{Daftar Pustaka}

[1] Afrizon, "Pertumbuhan Bibit Kelapa Sawit (Elaeis guineensis Jacq.) Dengan Pemberian Pupuk Organik dan Anorganik," AGRITEPA, vol. III, no. 2, pp. 95-105, 2017.

[2] I. R. Purba, Irsal, and Meiriani, "Hubungan Fraksi Kematangan Buah dan Ketinggian Tandan terhadap Jumlah Buah Memberondol pada Panen Kelapa Sawit (Elaeis guineensis Jacq) di Kebun Rambutan PTPN III," J. Agroekoteknologi FP USU, vol. 5, no. 2, pp. 315-328, 2017.

[3] Republik Indonesia, "Peraturan Menteri Pertanian Nomor 01 Tahun 2018 Tentang Pedoman Penetapan Harga Pembelian Tandan Buah Segar Kelapa Sawit.pdf." pp. 1-26, 2018.

[4] R. E. Caraka, H. Yasin, and A. W. Basyiruddin, "Peramalan Crude Palm Oil ( CPO ) Menggunakan Support Vector Regression Kernel Radial Basis,"J. Mat., vol. 7, no. 1, pp. 43-57, 2017.

[5] S. Andriyani and N. Sitohang, "Implementasi Metode Backpropagation Untuk Prediksi Harga Juanl Kelapa Sawit Berdasarkan Kualitas Buah," JURTEKSI (Jurnal Teknol. dan Sist. Informasi), vol. IV, no. 2, pp. 155-164, 2018.

[6] D. Rahayu, R. C. Wihandika, and R. S. Perdana, "Implementasi Metode Backpropagation Untuk Klasifikasi Kenaikan Harga Minyak Kelapa Sawit," J. Pengemb. Teknol. Inf. dan Ilmu Komput., vol. 2, no. 4, pp. 1547-1552, 2018.

[7] H. Aini, Haviluddin, E. Budiman, M. Wati, and N. Puspitasari, "Prediksi Produksi Minyak Kelapa Sawit Menggunakan Metode Backpropagation Neural Network," Sains, Apl. Komputasi dan Teknol. Inf., vol. 1, no. 1, pp. 24-33, 2019.

[8] D. L. Rahakbauw, F. J. Rianekuay, and Y. A. Lesnussa, "Penerapan Metode Fuzzy Mamdani Untuk Memprediksi Jumlah Produksi Karet (Studi Kasus: Data Persediaan Dan Permintaan Produksi Karet Pada Ptp Nusantara Xiv (Persero) Kebun Awaya, Teluk Elpaputih, Maluku-Indonesia)," J. Ilm. Mat. Dan Terap., vol. 16, no. 1, pp. 51-59, 2019.

[9] S. Y. Nababan and M. Harahap, "Implementasi Metode Tsukamoto Pada Analisis Prediksi Hasil," J. Penelit. Tek. Inform., vol. 3, no. 1, pp. 1-10, 2020.

[10] G. Tendra, "Implementasi Fuzzy Logic Mamdani Untuk Menentukan Kelayakan Calon Anggota Tamtama (CATAM) Tentara Negara Indonesia Angkatan Darat (TNI-AD)," J. PI-Cache, vol. 5, no. 1, pp. 1-11, 2016.

[11] M. Abrori and A. H. Prihamayu, "Aplikasi Logika Fuzzy Metode Mamdani Dalam Pengambilan Keputusan Penentuan Jumlah Produksi," Kaunia, vol. XI, no. 2, pp. 91-99, 2015.

[12] A. R. Wardani, Y. N. Nasution, and F. D. T. Amijaya, "Aplikasi Logika Fuzzy Dalam Mengoptimalkan Produksi Minyak Kelapa Sawit Di PT. Waru Kaltim Plantation Menggunakan Metode Mamdani," Inform. Mulawarman J. Ilm. Ilти Komput., vol. 12, no. 2, p. 94, 2017.

[13] M. Yusida, D. Kartini, A. Farmandi, R. A. Nugroho, and Muliadi, "Implementasi Fuzzy Tsukamoto Dalam Penentuan Kesesuaian Lahan Untuk Tanaman Karet Dan Kelapa Sawit," Klik - Kumpul. J. Ilmu Komput., vol. 4, no. 2, p. 233, 2017.

[14] A. Bahroini, A. Farmadi, and R. A. Nugroho, "Prediksi Permintaan Produk Mie Instan Dengan Metode Fuzzy Takagi-Sugeno," Klik - Kumpul. J. Ilmu Komput., vol. 3, no. 2, pp. 220-230, 2016.

[15] M. Destiningrum and Q. J. Adrian, "Sistem Informasi Penjadwalan Dokter Berbasis Web Dengan Menggunakan Framework Codeigniter (Studi Kasus: Rumah Sawit Yukum Medical Centre)," J. TEKNOINFO, vol. 11, no. 2, pp. 30-37, 2017. 
[16] B. Prasetyo, T. J. Pattiasina, and A. N. Soetarmono, "Perancangan dan Pembuatan Sistem Informasi Gudang ( Studi Kasus : PT . PLN ( Persero ) Area Surabaya Barat )," Teknika, vol. 4, no. 1, pp. 12-16, 2015.

[17] B. Putro, M. T. Furqon, and S. H. Wijoyo, "Prediksi Jumlah Kebutuhan Pemakaian Air Menggunakan Metode Exponential Smoothing ( Studi Kasus : PDAM Kota Malang )," J. Pengemb. Teknol. Inf. dan Ilmu Komput. Univ. Brawijaya, vol. 2, no. 11, pp. 4679-4686, 2018. 